BIOMEDICAL AND BIOSOCIAL ANTHROPOLOGY
$\begin{gathered}\text { Official Journal of the International Academy } \\ \text { of Integrative Anthropology } \\ \text { journal homepage: http://bba-journal.com }\end{gathered}$

\title{
Assessment of the quality of medical services to relatives of the mentally ill who are in inpatient treatment
}

\section{Chorna V. V. ${ }^{1}$, Makhniuk V. M. ${ }^{2}$, Khliestova S. S. ${ }^{1}$, Gumeniuk N. I. ${ }^{1}$}

${ }^{1}$ National Pirogov Memorial Medical University, Vinnytsya, Ukraine

${ }^{2} \mathrm{SU}$ "Institute of Public Health O. M. Marzeeva National Academy of Medical Sciences of Ukraine", Kyiv, Ukraine

\section{ARTICLE INFO}

Received: 04 August, 2020

Accepted: 02 September, 2020

UDC: $614.2: 005.336 .3: 616$

\section{CORRESPONDING AUTHOR}

e-mail: valentina.chorna65@gmail.com Chorna V. V.
The mental state of the mentally ill is one of the most important factors in the treatment of the patient by a medical professional. But aggression, high-pitched communication, indifference of a doctor or health care worker can negatively affect the outcome of treatment and recovery of a patient with mental and behavioral disorders. The problem of modern medical deontology in Ukraine is the stigmatization of health workers to patients with mental disorders, which lead to self-stigmatization of both patients and their families. The purpose of the study is to enable the relatives of mentally ill people undergoing long-term inpatient treatment, to determine the quality of medical services in a psychoneurological hospital, to identify ethical and deontological shortcomings in the doctor's relationship with relatives of mentally ill person, to determine the level of self-stigmatization in relatives of the patient by medical staff. The analysis of domestic and foreign scientific sources, bibliosemantic, analytical and statistical research methods were used in the work. A questionnaire was conducted (using a specially designed questionnaire) with elements of interviews of 92 respondents (relatives of mentally ill patients who were treated at a psychoneurological hospital in Vinnytsia). The results were processed using the licensed standardized package "Statistica 6.1". The need to comply with state building codes for health care facilities in accordance with European requirements has been proven. This will eliminate the feeling of hopelessness during hospitalization in public psychoneurological hospitals, which are a great trauma for relatives of patients. It has been shown that in order to prevent stigmatization of relatives of patients in psychoneurological hospitals, it is necessary to conduct trainings and interviews after training, which will determine the degree of stigmatization and subsequent preventive measures. It is shown that for relatives of mentally ill on the basis of psychoneurological hospitals it is necessary to equip rooms for psychodiagnostics and further psychocorrection. Development of affordable correctional programs for relatives of patients will reduce maladaptation and improve life satisfaction.

Keywords: families of the mentally ill, questionnaires with elements of interviews, the attitude of doctors to the relatives of the mentally ill, preventive measures for the families of patients with mental and behavioral disorders.

\section{Introduction}

The rapid development of modern technologies in the medical field significantly increases the effectiveness of diagnosis and treatment of patients in European countries. Unfortunately, in Ukraine, the constant, total underfunding of the health care sector has led to the neglected material and technical and sanitary and hygienic condition in public health care facilities, namely: extortion of patients; obsolete equipment, furniture and beds; bed linen from home; personal hygiene products and medicines for patients' money; insufficient disinfectants, etc. The premises of the health care facilities are in a terrible state of emergency and need major repairs. There is a growing trend of nontransparent procurement and use of medicines. Work on any preventive measures with the mentally ill has been suspended and, worst of all, the violation of the rules of professional ethics and the basics of deontological culture of medical staff in communication with the mentally ill, relatives of patients, attitude (stigmatization) of medical 
workers to patients, ie non-compliance Oaths of the doctor of Ukraine, the text of which was approved by the Decree of the President of Ukraine dated 15.06.1992 № 349, and which consists of all graduates of medical institutions of higher education of Ukraine [16].

The main international instruments governing patients' rights in the field of medicine are the WIA Lisbon Declaration on Patients' Rights (World International Association, 1981); Declaration on Patient Rights Policy in Europe, 1994; Council of Europe "Convention on Human Rights and Biomedicine", 1996; The EU Charter of Fundamental Rights, which in Article 6 declares the human right to safety and access to health care and medical assistance in order to achieve a high level of health care; WHO Patient Safety Program (World Alliance for Patient Safety, 2004); The WHO program for 2008-2009, which identified priority areas in the fight for safe health care [11].

However, ethical and deontological issues, namely the concept of "deontological culture", are ignored and do not find a place in the hearts of medical staff who work with the mentally ill and constantly communicate with their relatives or guardians. Every medical professional should have a basic understanding of the origins of medical deontology in order not to indulge in immoral things with patients, and especially with the mentally ill. Deontology is a science that studies the rules and norms of the duty of a specialist in the field of his professional activity. The term "deontology" was introduced into scientific circulation at the beginning of the nineteenth century by the English philosopher and jurist Jeremiah Bentham (1748-1832), to define the science of the professional duty of man $[2,10]$.

Summarizing the retrospective approaches and scientific statements of prominent scientists on the study of medical ethics and deontology, we recommend considering "deontological culture" as one of the most important components of professional culture and characterize it as a set of spiritual, intellectual and intellectual, which will help determine the significance and specificity of their professional activities [21].

Thus, the reflection of deontological requirements, professional norms in the mind of a medical professional will allow him to more fully and adequately perceive professional reality, navigate in it, develop strategy and tactics, goals and specific plans of professional activity, and recognition and acceptance of these norms as basic principles. professional duty will help him to form a proper attitude to the chosen profession and professional activity in general.

Under no circumstances should not patients' rights to emergency, highly qualified medical care be fully violated to all those who need it, regardless of age, social status, religion or race; humane treatment of the patient, and especially to patients with severe, incurable diseases or mental disorders; observance of confidentiality and medical secrecy as specified in the International Code of Medical Ethics "Geneva Declaration" adopted in 1949 [23].
Another problem of modern medical deontology in Ukraine is the stigmatization of health workers to HIVinfected patients, tuberculosis patients, currently COVID19 patients, and especially to patients with mental disorders and any mental health problems, which lead to selfstigmatization of both patients and their families, who are left alone in solving this problem.

In the EU countries, various measures have been introduced to stigmatize health workers in relation to patients, and measures are constantly taken to prevent and prevent such phenomena in society. The main principles in treatment in the EU are "restoration of human life", spiritual recovery of patients, reintegration into society and a full life. Forms for overcoming the stigma of health care workers in European countries are different, for example: training, coaching, psychological consultations with health care workers and relatives who care for relatives; persons caring for patients (for money or free of charge), etc. [12].

The Law of the Republic of Poland "On the Protection of Mental Health" ("Ustawa o ochronie zdrowia psychicznego"), which has been in force for 26 years (adopted on 19.08.1994) defines the term "mental health is the main personal good of a person, and protection the rights of persons with mental disorders are the duty of the state". This law regulates the rights of a psychiatric hospital patient who has the right to appoint an ombudsman, whose responsibilities include protecting the rights of patients with mental disorders in matters related to admission, treatment, conditions of stay and discharge from hospital, as well as access to medical care. documentation with the consent of the patient, guardian. Consultation, treatment of such patients is free, comprehensive (medical, social, legal) which is a great support for Polish citizens with mental disorders and the prospect of their socialization.

The purpose of the study is to enable the relatives of mentally ill people undergoing long-term inpatient treatment, to determine the quality of medical services in a psychoneurological hospital, to identify ethical and deontological shortcomings in the doctor's relationship with relatives of mentally ill, determine the level of selfstigmatization in relatives of the patient by medical staff.

\section{Materials and methods}

The analysis of domestic and foreign scientific sources, bibliosemantic, analytical and statistical research methods were used in the work.

92 respondents, relatives of the mentally ill, took part in the survey with elements of the interview. Patients with mental disorders were treated at the Vinnytsia Regional Clinical Psychoneurological Hospital named after Academician O. I. Yushchenko of the Vinnytsia Regional Council, of which men - $29.3 \%$ and women - $70.7 \%$, (under the age of $20-3.3 \%$, from 21 to 30 years $-9.8 \%$, from 31 to 40 years $-17.4 \%$, from 41 to 50 years $-33.7 \%$ and over 50 years $-35.9 \%$ ). Respondents with basic secondary 
education - $10.9 \%$, specialized secondary education $23.9 \%$, vocational education - $30.4 \%$, higher education $34.8 \%$ took part in the survey with elements of interviews. The survey was conducted using a specially designed questionnaire: "Method of determining the quality of medical care by relatives of a patient in a psychiatric hospital and the relationship "doctor-relative"", recognized as an innovation from 16.01.2020 and registered in the journal of innovation proposals National Pirogov Memorial Medical University, Vinnytsya for № 2 and "Method of determining the personal opinion of the patient's relatives about the payment of medical care in a psychiatric hospital" from 16.01.2020 and registered in the register of innovation proposals of National Pirogov Memorial Medical University, Vinnytsya for № 3 .

The results of the questionnaire were processed using the licensed standardized package "Statistica 6.1".

\section{Results}

Conditions of patients' stay in psychiatric hospitals of Ukraine encourage patients and their relatives to seek medical help in psychiatric hospitals only in case of exacerbated diseases (crisis conditions): deterioration of health of the total number of respondents- $68.5 \%$; reregistration of disability group for mental disorders $21.7 \%$; the psychogenic load of family and household nature $-8.7 \%$ (Table 1 ).

According to the survey of relatives of inpatients, $32.6 \%$ of the total number of respondents applied to a psychiatric hospital without a referral $(37.0 \%$ of them were male relatives and $30.8 \%$ were female relatives); according to the direction of the psychoneurologist of the polyclinic $27.2 \%(29.2 \%$ of them are female relatives and $22.2 \%$ are male relatives); in the referral of a family doctor $-22.8 \%$ (of which $23.1 \%$ - female relatives and $22.2 \%$ - male relatives); $10.0 \%$ of the total number of respondents (of whom $11.1 \%$ were male relatives and $10.8 \%$ were female relatives) were referred by a psychoneurological dispensary; an ambulance crew took $6.0 \%$ of patients to a psychoneurological hospital on call of relatives $(7.4 \%$ of

Table 1. The results of a survey of relatives of patients on the reasons for seeking psychiatric care for hospitalization in a psychoneurological hospital (\%).

\begin{tabular}{|c|c|c|c|c|}
\hline \multirow{2}{*}{$\begin{array}{c}\text { Relatives of } \\
\text { patients }\end{array}$} & $\begin{array}{c}\text { re-registration } \\
\text { of the } \\
\text { disability } \\
\text { wroup for } \\
\text { mental } \\
\text { disorders }\end{array}$ & $\begin{array}{c}\text { due to the } \\
\text { psychogenic } \\
\text { burden of } \\
\text { family and } \\
\text { domestic } \\
\text { nature }\end{array}$ & $\begin{array}{c}\text { Reason } \\
\text { the } \\
\text { is not } \\
\text { specified }\end{array}$ \\
\hline $\begin{array}{c}\text { Male } \\
\text { relatives }\end{array}$ & 74.1 & 18.5 & 3.7 & 3.7 \\
\hline $\begin{array}{c}\text { Female } \\
\text { relatives }\end{array}$ & 66.2 & 23.1 & 10.7 & 0 \\
\hline $\begin{array}{c}\text { Total of all } \\
\text { respondents }\end{array}$ & 68.5 & 21.7 & 8.7 & 1.1 \\
\hline
\end{tabular}

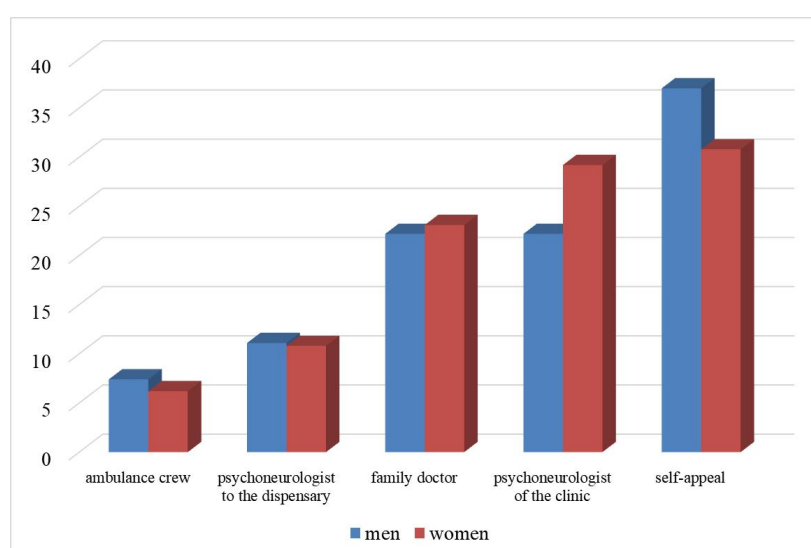

Fig. 1. The results of a survey of relatives of patients with mental disorders to the question "Who sent your relative for treatment in a psychiatric hospital?" (\%).

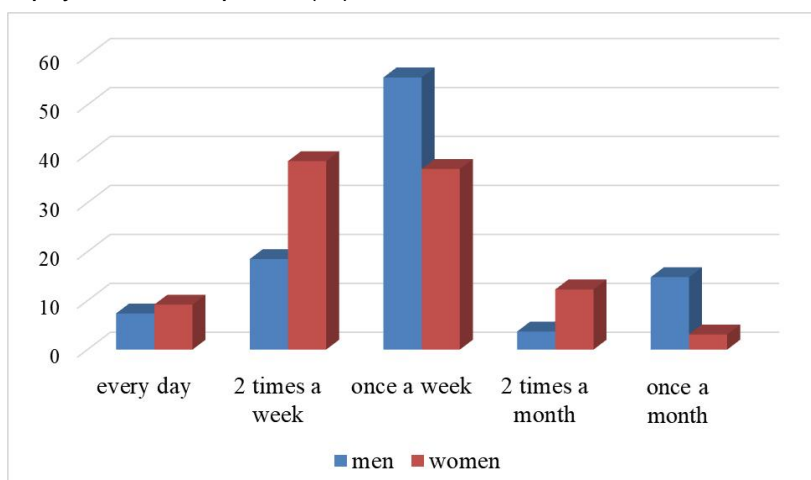

Fig. 2. The results of a survey of relatives of patients on the frequency of meetings with the attending physician (\%).

them were male relatives and $6.2 \%$ were female relatives) (Fig. 1).

In the questionnaire to the question "How often do you meet with your relative's doctor?", the following answers were received from relatives of patients: every day when visiting their sick relative they talked to a doctor $-8.7 \%$ of the total number of respondents (of which $7.4 \%$ - male relatives and $9.2 \%$ - female relatives); twice a week talked to a doctor - $32.6 \%$ (of which $18.5 \%$ - male relatives and $38.5 \%$ - female relatives); once a week - $42.4 \%$ (of which $55.6 \%$ were male relatives and $36.9 \%$ were female relatives), talked to the doctor twice a month - $9.8 \%$ (of which $3.7 \%$ - male relatives and $12.3 \%$ - female relatives) and only $6.5 \%$ of the total number of respondents (of whom $14.8 \%$ - male relatives and $3.1 \%$ - female relatives) communicated once a month due to the fact that they visited their sick relatives rarely because they get to hospital them more than three hours (Fig. 2).

In the questionnaire "How often do you visit your sick relative?", the following answers were received from relatives of patients: every day they visited their sick relative $-28.3 \%$ of the total number of respondents (of which $29.6 \%$ - male relatives and $27.7 \%$ - relatives-women); twice a week - $33.7 \%$ (of which $29.6 \%$ were male relatives and $35.4 \%$ were female relatives); once a week - $25.0 \%$ 


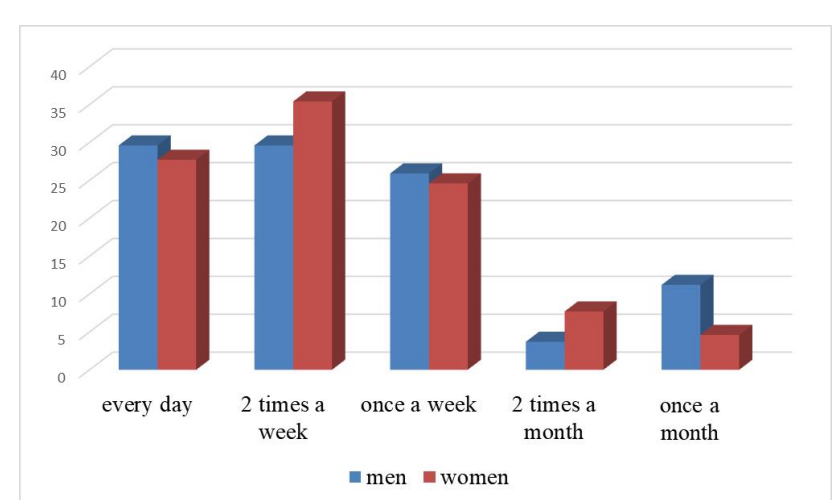

Fig. 3. Results of the survey relatives of patients on the frequency of visits patients in hospital (\%).

Table 2. The results of a survey of relatives of patients in a psychoneurological hospital to participate in rehabilitation programs, provided that they were offered (\%).

\begin{tabular}{|c|c|c|}
\hline $\begin{array}{c}\text { Names of rehabilitation programs for relatives of } \\
\text { the mentally ill }\end{array}$ & $\begin{array}{c}\text { Male } \\
\text { relatives }\end{array}$ & $\begin{array}{c}\text { Female } \\
\text { relatives }\end{array}$ \\
\hline Educational program for relatives & 85.2 & 76.9 \\
\hline $\begin{array}{c}\text { Trainings on prevention of chronic fatigue } \\
\text { syndrome }\end{array}$ & 81.5 & 56.9 \\
\hline $\begin{array}{c}\text { Trainings on development of skills of } \\
\text { communication with sick relatives }\end{array}$ & 66.7 & 50.7 \\
\hline Trainings on prevention of self-stigmatization & 7.4 & 27.7 \\
\hline $\begin{array}{c}\text { Trainings on development of skills of } \\
\text { communication with the doctor }\end{array}$ & 7.4 & 3.1 \\
\hline
\end{tabular}

(of which $25.9 \%$ are male relatives and $24.6 \%$ are female relatives), visited their sick relatives twice a month $-6.5 \%$ (of which $3.7 \%$ - male relatives and $7.7 \%$ - female relatives) and $6.5 \%$ of the total number of respondents (of whom $11.2 \%$ - male relatives and $4.6 \%$ - female relatives) visited sick relatives once a month due to the fact that they get to the hospital more than three hours (Fig. 3).

According to the results of our research, we established the time spent by relatives waiting for a doctor to communicate about a relative. Of the total number of respondents $-68.5 \%$ of relatives of patients waited up to 30 minutes; $29.3 \%$ - from 30 minutes to one hour; $2.2 \%$ from one hour to two hours, while the doctors of the psychoneurological hospital are not urgent, emergency doctors. But the generally accepted ethical principles in the daily activities of a doctor are: trust, openness, the desire to be useful to the patient, to be able to put himself in the place of the patient, to look at the world through his eyes. All the variety of approaches to the cooperation of the doctor and the relative of the mentally ill should be manifested in emotional support, understanding, respect and compassion.

The doctor's respect for the patient's relative should be manifested in his recognition as an individual. It is necessary not only to write a long list of drugs, but also to listen to the person, the main thing - to show that his words are important to him, to recognize the significance of events that bother the patient's relative because he has no one to share with the "burden" he carries all life. Therefore, we also investigated how much time the doctor spent talking to a relative of the patient: up to 10 minutes the doctor talked about the patient from the total number of respondents - $52.2 \%$; from 10 to 20 minutes - $42.4 \%$ and only $-5.4 \%$ of doctors talked from 20 to 30 minutes, from 30 minutes and more - there were no such doctors. According to the results of the survey, female relatives talked to doctors for the longest time, from 10 to 20 minutes - 43.1 $\%$, and among male relatives - $40.7 \%$; only female relatives communicated from 20 to 30 minutes $-7.7 \%$.

In analyzing the questionnaires, we found that $54.3 \%$ of the total number of respondents agreed that they had enough time to resolve all issues with the attending physician about their relative, and $45.7 \%$ of relatives did not have enough time. Therefore, $32.6 \%$ of relatives out of the total number of respondents thought that the doctor did not fully understand the patient's problem. Doctors must honestly perform their professional duties and remember the words of the Oath of the Doctor of Ukraine: "I do not cure a disease, but a living person".

Research on the structure of difficulties that arise in families with mental disorders and faced by the family - is the financial cost of treatment in a psychoneurological hospital for the purchase of products - $96.0 \%$, for drugs $85.3 \%$, for personal care hygiene $-81.3 \%$ and on the way to the hospital $-68.0 \%$ of the total number of respondents.

Relatives who took part in any programs on psychocorrectional and psycho-educational measures accounted for only $3.3 \%$ of the total number of respondents, and the remaining $96.7 \%$ did not take or did not know about such measures. We proposed a list of programs in which they would like to participate and get the following results (Table 2).

According to the survey, it was found that $85.2 \%$ of men who care for their sick wives need communication, support, participation in psycho-educational programs; $81.5 \%$ of men want to participate in programs for the prevention of chronic fatigue syndrome; $66.7 \%$ of men want to take part in programs for communication and understanding with a sick woman. Female relatives also most often choose such programs (see Table 2). In addition, in contrast to men, female relatives quite often $(27.7 \%)$ choose trainings on prevention of self-stigmatization (see Table 2).

\section{Discussion}

According to the results of the monitoring of the Ukrainian Helsinki Union in three regional psychoneurological hospitals (Mykolaiv, Poltava, Kherson) and according to its analytical report on human rights in 2015 , the lack of material and technical and sanitary conditions of psychiatric facilities in Ukraine is practically repeated: patient privacy - we are talking about noncompliance with the area per patient (6 m2), but after the second stage of medical reform from April 1, 2020 in the field of psychiatry, after reducing inpatient care for patients 


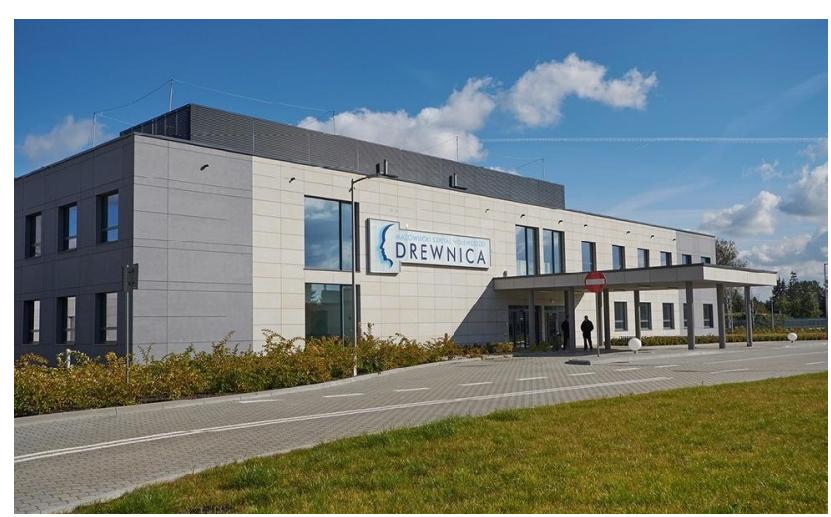

Fig. 4. View of Drevnica Psychiatric Hospital in Ząbki (Republic of Poland).

today this rule is met, but the following shortcomings remain: old furniture and bed linen; bathrooms and toilets are located away from the wards; bath day once a week, and only then patients receive clean linen; eating clearly on schedule; telephone use is limited, etc. [9].

For comparison, the psychoneurological hospital in Ząbki within the walls of former military barracks began operating in 1903 at the initiative of doctor and public figure Pelagia Poplawska, who received medical education in Switzerland and founded the Warsaw Society of Medical Care and Care for Mental and Nervous Diseases. In 2018, a modern complex of new buildings (Pas Projekt Archi Studio) was opened. The architects considered the needs of patients as much as possible: music therapy rooms, rehabilitation center, cafe, reading room, conference hall, winter hall, etc. (Fig. 4).

After deinstitutionalization in European countries during the reconstruction, construction of psychiatric health facilities, the following interior elements are observed, which take into account the average length of stay of patients, features of diagnoses, severity of diseases, age and degree of medical conditions, safety of patients and medical staff, convenience and the comfort of using its equipment, provide the conditions for patients to stay in a "typical living environment" to return the patient to normal life as soon as possible. Architects from European countries work closely with hospital staff, patient groups, interior designers and psychiatric hospital consultants [3, 6].

In Ukraine, after the reform in the field of health care, the issue of the first diagnosis of patients with mental disorders, the issuance of prescriptions for psychotropic drugs, referral for inpatient treatment is entrusted to primary care physicians. As a result of insufficient psychiatric qualifications for a family doctor, there is a certain professional complexity. Therefore, very often family doctors turn to specialists (psychiatrists, neurologists of district or regional medical institutions) for help on the above specific issues.

Interpersonal relations between a doctor and a relative of a patient with mental disorders should be based on the principle of practical interaction and mutual assistance because trust as a moral and psychological trait determines the doctor's attitude to the patient. Trust is a necessary component in treatment and an integral part of communication between the doctor, the patient and his relatives. It helps to improve relationships and helps to achieve a successful therapeutic effect in the treatment process, which accelerates the patient's recovery, stimulates their interest in life and increases the emotional state of relatives who are constantly with aggressive, conflicted, unbalanced patients, long-term communication with which emotionally devastates them. However, patients with mental illness remember well the general aspects of communication with the doctor, attitude to him, when communicating patients assess the professionalism of the doctor and the degree of trust in him [13, 15].

According to a survey of relatives of patients on the frequency of visits to the doctor and a survey of relatives of patients on the frequency of visits to their relatives in the hospital, we observe self-stigmatization, which manifests itself in "cornering" and "carrying the burden alone." This is typical only for our country, which is considered to be a country with a low level of quality of life.

The Human Development Index in Ukraine increased from 0.705 to 0.750 , but the growth rate of the consolidated budget expenditures on health care to gross domestic product compared to $1995 / 2015$, the total amount of expenditures decreased by $25.0 \%$ (so in 2013 it was $12.2 \%$, in 2016-2017 - $4.2 \%$ and in $2018-2.5 \%$ of gross domestic product) and therefore the quality of life of the population of Ukraine is lower than the standards set by the United Nations [4, 5, 7].

Today's stigmatization depends on the level of solidarity, integration, and humanity of society. Characteristic features of our society in relation to the mentally ill and their relatives are the following:

- social contempt, mistrust, prejudice and fear, which leads to self-stigmatization of relatives;

- dissatisfaction with their sick relatives, shame and pain;

- lack of information about the course of the disease and limited or complete lack of knowledge about how to behave with a sick relative;

- hopelessness in hospitalization in state psychiatric hospitals, which is a great trauma for their sick relatives (life in a "cage" without hopes for the best and personal unrealization);

- decreased self-esteem because long-term care of their sick relatives [1].

In European countries, constant attention is paid to stigmatization of patients with mental disorders, so such patients find support not only from government agencies (medical, social), but also from NGOs, various denominations, community volunteers and more. The main approaches to the mentally ill abroad use the following principles: balanced care, treatment and rehabilitation, which are the basis for a measured approach to health [17]. 
According to Nie J. B. et al. [14] in China, with the participation of 107 doctors and nurses, they examined medical professionalism through interviews. The analysis revealed distrust, escalation of conflicts, disputes between patients and their relatives and doctors. The vicious circle pointed not only to the crisis of the patient-physician relationship, but also to the crisis of medicine as a profession and institution, which seriously jeopardized the basic principle of medical professionalism that characterizes the traditional Chinese ideal of "medicine as an art of mankind".

According to the results of recent studies, the possibility of signs of somatic disease, anxiety and depression, as well as predictors of emotional burnout was established $[8,19,22]$. The study by Ruiz-Fern?ndez M. D. et al. [18] showed a direct relationship between the degree and severity of the disease in patients with mental disorders on the percentage of somatic diseases in healthy individuals who cared for these patients. Also, caregivers of patients with mild Alzheimer's disease were found to have $46.3 \%$ of somatic diseases, and those who cared for patients with moderate Alzheimer's disease had $61.9 \%$ of mental health disorders.

According to Skoda K. V. [20], women who cared for sick relatives with mental illness at the Kharkiv Regional Psychoneurological Dispensary from 2012 to 2016 were found to have: depressive syndrome in $64.5 \%$ of wives and $74.0 \%$ of mothers of mentally ill people; anxietydepressive syndrome in $80.1 \%$ of wives and $70.8 \%$ of mothers of mentally ill; vegetative-somatic complaints in

\section{References}

[1] Basiy, R. М. (2017). Стигматизація психічно хворих з погляду їхніх родичів на прикладі фокус-групового дослідження матерів психічно хворих [Stigmatization of the mentally ill from their relatives on the example of focus group research of materials of the mentally ill]. Наукові записки НаУКМА. Соціологічні науки - Scientific notes of NaUKMA. Social sciences, (196), 73-78.

[2] Bentham, J. (1834). Deontologie: ou, Science de la morale. ouvrage posthume (Vol. 1). Charpentier

[3] Chorna, V. V. (2020). Детермінація психічного здоров'я населення в Україні та країнах ЄС [Determination of menta health of the population of Ukraine and EU countries]. Довкілля та здоров'я - Environment and health, 2(95), 47-53. doi: 10.32402/dovkil2020.02.047

[4] Chorna, V. V., Khliestova, S. S., Gumeniuk, N. I., Makhniuk, V. M., \& Sydorchuk, T. М. (2020). Показники захворюваності і поширеності та сучасні погляди на профілактику хвороб [Incidence and prevalence rates and current views on disease prevention]. Вісник Вінницького національного медичного університеmy - Bulletin of Vinnytsia National Medical University, 24(1), 158-164. doi: 10.31393/reports-vnmedical2020-24(1)-31

[5] Chorna, V., Makhniuk, V., Gumeniuk, N., Khliestova, S. \& Tomashevskyi, A. (2020). Comparative analysis of morbidity indicators among the population of the eu and Ukraine under conditions of stressed load of the Anti-terrorist operations and psychoprophylaxis measures. Georgian medical al news,
$37.3 \%$ of wives and $48.1 \%$ of mothers of mentally ill; signs of anxiety-phobic syndrome in $21.7 \%$ of wives and $11.0 \%$ of mothers of mentally ill.

Therefore, psychoneurological hospitals should not only treat patients in crisis, but also conduct psycho-correctional and psycho-educational activities for relatives of patients with mental disorders due to the fact that medical psychological centers for rehabilitation of relatives of patients have not yet been established, but there are only such centers for ATO/JFO soldiers in Ukraine.

\section{Conclusions}

1. State building codes "Health care facilities" must be implemented in accordance with European requirements, to avoid the feeling of hopelessness when hospitalized in public psychoneurological hospitals, which are a great trauma for patients and their relatives.

2. To prevent stigmatization of relatives of patients in psychoneurological hospitals there is need to conduct their training, post-training interviews to determine the degree of stigmatization and subsequent preventive measures.

3 . For relatives of the mentally ill on the basis of psychoneurological hospitals it is necessary to equip rooms for psychodiagnostics and further psychocorrection.

4. It is necessary to develop and implement educational and psychological training in psychiatric hospitals, as well as the development of affordable correctional programs for relatives of the patient to reduce maladaptation and improve life satisfaction.

5(302), 147-154

[6] Chorna, V. V., Sergeta, I. V., \& Makhnyuk, V. M. (2019). Modern going near creation of in-hospital comfort for patients and medical personnel in psychiatric establishments of health protection. Biomedical and Biosocial Anthropology, (35), 4853. doi: $10.31393 /$ bba34-2019-08

[7] Hanlon, C. (2017). Next steps for meeting the needs of people with severe mental illness in low-and middle-income countries. Epidemiology and psychiatric sciences, 26(4), 348-354. doi: 10.1017/S2045796016001013

[8] Hou, R. J., Wong, S. Y. S., Yip, B. H. K., Hung, A. T., Lo, H. H. M., Chan, P. H., ... \& Mercer, S. W. (2014). The effects of mindfulness-based stress reduction program on the mental health of family caregivers: a randomized controlled trial. Psychotherapy and psychosomatics, 83(1), 45-53. doi: $10.1159 / 000353278$

[9] Imerelli, R. E, Kazachinskaya, K. P, Moisa, B. S, \& Shum, S. S. (2016). Права осіб із проблемами психічного здоров'я. Дотримання прав людини у психіатричних лікарнях [Rights of persons with mental health problems. Respect for human rights in psychiatric hospitals]. Analytical report of the Ukrainian Helsinki Human Rights Union. Ukrainian Helsinki Human Rights Union. K.: KIT.

[10] Khlestova, S. S. (2015). Що повинні знати майбутні лікарі про витоки медичної деонтології [What future doctors should know about the origins of medical deontology]. Вісник проблем біології і медицини - Bulletin of problems of biology 
and medicine, 3(2), 66-69.

[11] Kovaleva, O. M., Safargalina-Kornilova, N. A., \& Gerasimchuk, N. М. (2014). Деонтологія в медицині: підручник [Deontolonia in medicine: a textbook]. Kharkiv: XHMY.

[12] Mall, S., Hailemariam, M., Selamu, M., Fekadu, A., Lund, C., Patel, V., ... \& Hanlon, C. (2017). 'Restoring the person's life': a qualitative study to inform development of care for people with severe mental disorders in rural Ethiopia. Epidemiology and Psychiatric Sciences, 26(1), 43-52. doi: 10.3390/ ijerph16193762

[13] McBride, J. L. (2016). Family physician support for a family with a mentally ill member. The Annals of Family Medicine, 14(5), 460-462. doi: 10.1370/afm.1969

[14] Nie, J. B., Cheng, Y., Zou, X., Gong, N., Tucker, J. D., Wong, B., \& Kleinman, A. (2018). The vicious circle of patient-physician mistrust in China: Health professionals' perspectives, institutional conflict of interest, and building trust through medical professionalism. Developing World Bioethics, 18(1), 26-36. doi: 10.1111/dewb.12170

[15] Paternotte, E., van Dulmen, S., Bank, L., Seeleman, C., Scherpbier, A., \& Scheele, F. (2017). Intercultural communication through the eyes of patients: experiences and preferences. International journal of medical education, 8, 170. https://doi.org/10.5116/ijme.591b19f9

[16] Popovich, Yа. М. (2018). Особливості медичної етики та деонтології [Features of medical ethics and deontology]. Медсестринство - Nursing, (3), 11-14.

[17] Raviola, G., Naslund, J. A., Smith, S. L., \& Patel, V. (2019). Innovative models in mental health delivery systems: task sharing care with non-specialist providers to close the mental health treatment gap. Current psychiatry reports, 21(6), 44. doi: 10.1007/s11920-019-1028-x

[18] Ruiz-Fernandez, M. D., Hernandez-Padilla, J. M., Ortiz-Amo, R., Fernandez-Sola, C., Fernandez-Medina, I. M., \& Granero-
Molina, J. (2019). Predictor factors of perceived health in family caregivers of people diagnosed with mild or moderate Alzheimer's disease. International journal of environmental research and public health, 16(19), 3762. doi: 10.3390/ ijerph16193762

[19] Shakiba Zahed, M. E., Eslami, A. A., Barekatain, M., Hassanzadeh, A., \& Zamani-Alavijeh, F. (2020). Stress as a challenge in promoting mental health among dementia caregivers. Journal of Education and Health Promotion, 9, 65. doi: 10.4103/jehp.jehp_445_19

[20] Skoda, K.V. (2016). Клініко-психологічна характеристика і комплексна психокорекція дезадаптації у дружин та матерів хворих на параноїдну шизофренію з тривалими термінами захворювання та іï ефективність [Clinical and psychological characteristics and complex psycho-correction of maladaptation in wives and mothers of patients with paranoid schizophrenia with long-term disease and its effectiveness]. Вісник наукових досліджень - Bulletin of scientific research, (4), 108-113. doi: 10.11603/24158798.2016.4.7160

[21] Vainola, R. K., \& Khliestova, S. S. (2017). Characteristics of the experimental work on the formation of university students' deontological culture in the process of socio-educational work. Science and Education, (4), 63-67. doi: 10.24195/2414-46652017-4-11

[22] Whitebird, R. R., Kreitzer, M., Crain, A. L., Lewis, B. A., Hanson, L. R., \& Enstad, C. J. (2013). Mindfulness-based stress reduction for family caregivers: a randomized controlled trial. The Gerontologist, 53(4), 676-686. doi: 10.1093/geront/ gns 123

[23] World Medical Association. (1949). Declaration of Geneva: a pledge suggested as a dedication of the physician to his profession ofservice. World Med Assoc Bull, 1, 35. 